\title{
A DUAL PERSPECTIVE OF VALUE IN A BUNDLE OF PRODUCT AND SERVICE
}

\author{
Niusha Safarpour ${ }^{1}$, Ilkka Sillanpää² \\ ${ }^{1}$ Department of Industrial Engineering and Management, Tampere University of Technology, Finland \\ ${ }^{2}$ Department of Management, University of Vaasa, Finland
}

Corresponding author:

Niusha Safarpour

Department of Industrial Engineering and Management

Tampere University of Technology

Korkeakoulunkatu 10, FI-33720 Tampere, Finland

PO Box 527, FI-33101

phone: (+98) 9125498575

e-mail: niusha.s90@gmail.com

Received: 1 November 2016 Accepted: 9 November 2017

\section{Abstract}

Focusing on value creation in marketing has always been the key to success for companies. As a result, the definition, analysis and communication of value has gained importance. Companies are making an attempt to make a value proposition that is not only lucrative for the customer, but also has great returns for the company itself. Although this might sound simple on paper, since it is the basis for business logic, it is much more complicated in real life situations. With the service elements in the offering and the emergence of technologies such as smart and connected phenomenon, the business models become more innovative and more complexity is added to the analysis of value.

The objective of this paper is to introduce a method for the dual perspective of value in a bundle of product and service in a smart and connected context. This method draws from the customer value and customer lifetime value concepts to offer an all-inclusive study on value. This assists companies in crafting an appealing value proposition in a cost-saving offering for a client that offers value to the company over its lifetime. This study specifically deals with the state of the arts smart and connected phenomenon and provides a view on how value works in that context.

The framework created through this study serves to help the company choose a client that is of most value to the firm over the time of their cooperation. It then leads the company towards a better fabrication of the offering that is not only an attractive proposition to the client but also for the company. It gives a close insight onto where the benefit comes from and how a smart and connected bundle of products, services and relationships must be put together for maximum results in the modern age.

KEYWORDS

customer value, value proposition, customer life-time value, service, smart and connected.

\section{Introduction}

Value creation lies in innovative development of bundles of products and services and offering a unique value proposition to the right market [1]. A technology has no value unless it is commercialized through a well-planned business model [2]. As new knowledge is created, it can be put to use in established industries for enhanced efficiency [3]. An innovative offering is capital and resource intensive and time consuming hence must be fully exploited
[2]. At times, a certain technology can have value to different entities. The company must assess the holistic value of different entities for it alongside the value it can create for them [4]. There is need for a holistic value proposition assessment that considers the duality of value, as seen by the client and the company.

If this gap in value assessment models is filled, certain strategic decisions can be made with more research-based evidence and certainty. The selection of partner clients can be focused on the most prof- 
itable ones. The development of value proposition can then be based on the opinion of the value partners. The value proposition customization then is done considering the value capture model for the firm itself.

This paper introduces a new value assessment model and the model considers the benefits and expenses of product, service and relationship. It views value from both co-creation partners' points of view. With the cloud systems as a new tool for service based on big data analysis, the development of a value-adding service concept is complicated. However, through insightful view, it can be very rewarding. The framework hence guides the development of the offering, partner selection and value analysis and communication. Thus, the objective of this paper is...

... to develop a framework for analyzing a dual perspective of customer value in the context of an innovative smart and connected product - service bundle.

To fulfill this objective, the paper reviews the literature on value. Then a framework is designed to analyze the benefits and costs to all parties in order to demonstrate customer perceived value and customer lifetime value at one glance. The technology being innovated in the context of the smart and connected phenomenon, impacts different components of value. Eventually, this framework is tested in a costreducing offering development in the case project.

\section{Research methodology}

This paper is a qualitative study of the dual nature of value. The purpose of this research is to develop a framework for analysis of value from both client and company perspective. In order to fulfill that goal, the rivals and potential partner clients were studied. The case that this research is based on made the phenomenon more tangible. This resulted in an easier and more efficient development of the framework and a more thorough analysis. The framework is hence more beneficial if applied in another real life example.

The research method that resulted in the ideas presented in this paper were found through case study. The case was the commercialization of an innovative idea that would revolutionize the measurement of suspension characteristics in the ceramics business. The goal of this research was to use the theoretical framework for the analysis of the value surrounding a smart and connected product-service offering bundle. The investigation for the purpose of this research was done through extensive market re- search through existing material, meaning media and secondary sources of data. The rival offerings were found through their existing sales material on the internet. The different people on the team were interviewed. The members who worked directly with the cooperation partners were asked to share their observations of the client's current practices, needs and expectations. The people who worked on the technical side of the offering were also kept in touch with.

\section{Value creation}

\section{Value}

Value has been studied in literature in accordance with different disciplines. Building a business around it increases the likelihood of success [5-7]. The significance of value spans from a tool for pricing $[8,9]$ to a source of competitive advantage [10-12]. It has been studied in both business to business $[13,14]$ and business to consumer settings. Regardless of the vast literature on value, it is still a controversial topic. To begin with, the definition has been quite ambiguous $[15,16]$.

It is confirmed by scholars $[11,15,17]$ that proposing a definition for customer value is difficult. Value is subjective for each customer [18, 19], conditional to the context of use, relative to competition and dynamic over time [20-22]. They change, due to competition, promotional efforts, changing consumer perception and information [23]. Table 1 summarizes different value definitions through literature.

Some of these definitions focus solely on the monetary nature of the value [23] and overlook the markets where more non-monetary and intangible benefits contribute to the choice [24, 26]. Eggert and Wolfgang (2009) offer an insightful definition for business market [30]. In a review on value literature Khalifa (2004) has categorized the value definitions into three groups [35]. These categories are means-end models, value component, means-end and benefit costs models. However, this categorization does not seem very logical due to the admitted overlap between categories. The more recent studies take into consideration the importance of customer value over time and in the relationship context [31-33].

Some authors also pay attention to the element of competition in customers' perception of value $[25$, $28,36]$. This seems like a legitimate consideration. To create superior value, the firms' resources and core capabilities must be used to deliver a competitive offering [1]. In other words, value always finds significance in comparison to other options. It can be said that value is relative and not absolute. 
Table 1

Definition of value in literature.

\begin{tabular}{|c|c|}
\hline Value definition & Author \\
\hline Sheth et al. (1991) & $\begin{array}{l}\text { "The five values influencing market choice behavior are functional value, social value, emotional } \\
\text { value, epistemic value and conditional value." }[24]\end{array}$ \\
\hline Anderson et al. (1993) & $\begin{array}{l}\text { "Perceived worth in monetary units of the set of economic, technical, service, and social benefits } \\
\text { received by a customer firm in exchange for the price paid for a product offering, taking into } \\
\text { consideration the available alternative suppliers' offerings and price." }[25]\end{array}$ \\
\hline $\begin{array}{l}\text { Butz } \\
\text { and Goodstein (1997) }\end{array}$ & $\begin{array}{l}\text { "By customer value is meant the emotional blond established between a customer and a producer } \\
\text { after the customer had used a salient product or service produced by that supplier and found } \\
\text { the product to provide an added value." [26] }\end{array}$ \\
\hline Woodruff (1997) & $\begin{array}{l}\text { "Customer value is a customer perceived preference for an evaluation of those product attributes, } \\
\text { attribute performances, and consequences arising from use that facilitate (or block) achieving } \\
\text { the customer's goals and purposes in use situations." [12] }\end{array}$ \\
\hline Grönroos (1996) & $\begin{array}{l}\text { "Customer-perceived value can be described as core solution plus additional services divided by } \\
\text { price and relationship costs or core plus/minus added value." }[27]\end{array}$ \\
\hline $\begin{array}{l}\text { Gassenheimer } \\
\text { et al. (1998) }\end{array}$ & $\begin{array}{l}\text { "The sum of transactional cost advantages and constraints together with the emotional cost and } \\
\text { benefits in relative to alternative options." }[28]\end{array}$ \\
\hline $\begin{array}{l}\text { Doyle }(2008) \\
\text { Kotler }(1972)\end{array}$ & $\begin{array}{l}\text { The perceived product benefits minus the product price and cost of ownership, e.g. Installation, } \\
\text { training, maintenance and risks and uncertainties associated with switching suppliers. }[7,29]\end{array}$ \\
\hline $\begin{array}{l}\text { Kothandaraman } \\
\text { and Wilson (2001) }\end{array}$ & "Value is the relationship between the competing market offerings and their respective prices." [1] \\
\hline $\begin{array}{l}\text { Eggert and Wolfgang } \\
(2002)\end{array}$ & $\begin{array}{l}\text { "In the B2B-context, customer perceived value is conceptualized by cognitive construct, pre- } \\
\text { / post-purchase perspective, strategic orientation, present and potential customers and suppliers' } \\
\text { and competitors' offerings." [30] }\end{array}$ \\
\hline Woodall (2003) & $\begin{array}{l}\text { "Value for the customer is any demand-side, personal perception of advantage arising out of } \\
\text { a customer's association with an organization's offering, and can occur as reduction in sacrifice } \\
\text { and benefit (determined and expressed either rationally or intuitively); or an aggregation, over } \\
\text { time, of any of all of those." [31] }\end{array}$ \\
\hline $\begin{array}{l}\text { Liu (2006) } \\
\text { Han and Sung (2008) }\end{array}$ & $\begin{array}{l}\text { "Customer value for a business service is defined }[\ldots] \text { as an organizational buyer's assessment } \\
\text { of the economic, technical, and relational benefits received, in exchange for the price paid for } \\
\text { a supplier's offer to competitive alternatives." }[32,33]\end{array}$ \\
\hline Blocker (2011) & $\begin{array}{l}\text { "Customer value in B2B contexts is defined as the customer's perceived trade-off between ben- } \\
\text { efits and sacrifices within relationships." }[34]\end{array}$ \\
\hline
\end{tabular}

Another recurring concept in most of value studies is the perceived nature of value. Value as seen by the customer must be explored, created and delivered. Kothandaraman and Wilson (2001) aptly state: "Value is in the eye of the beholder".

As evident from the summary above, the definition has been quite ambiguous [15, 16]. Value is created when the benefits of a strategic activity exceed the cost [37]. All the definitions acknowledge that value is strictly related to customer perception of the benefit as opposed to the offering itself and the features $[5,7,23]$.

$$
\text { Benefits }_{0}-\text { Expenses }_{0}>\text { Benefits }_{A}-\text { Expenses }_{A} \text {. }
$$

According to the equation number 1, the customer has more tendency to opt for the firm's offering if only the benefits it offers compared to the price is more than that of the alternative [1]. Woodruff (1996) categorizes value further based on whose benefit is taken into account, a broad network, the supplier or the customer [12]. A business prevails if it provides value for three constituents: customers, employees and investors [38].

There are other sides to value besides that perceived by customer. While customer value is defined from the customer perspective, customers' value is the value of an individual customer to the organization. Hence, these three categories co-exist, with customer value at the core [39] Customer lifetime value is one side of the coin. If prospective clients for a relationship are to be chosen customer lifetime value must be looked into.

The other side of the coin is the customer value, which is the value the company offers the customers. The reason behind such an emphasis on customer value is how it effects customer's perception of the offering and the brand. It later on has an impact on customers' adoption decision. Along with customer satisfaction of the value proposition comes loyalty in the long-term [38] and possibility of building a relationship. Common consensus about value is the customers' perception of the trade-off between what is 
received, namely quality and what is given, namely money, time and effort [23, 40-43]. Figure 1 illustrates value simply.

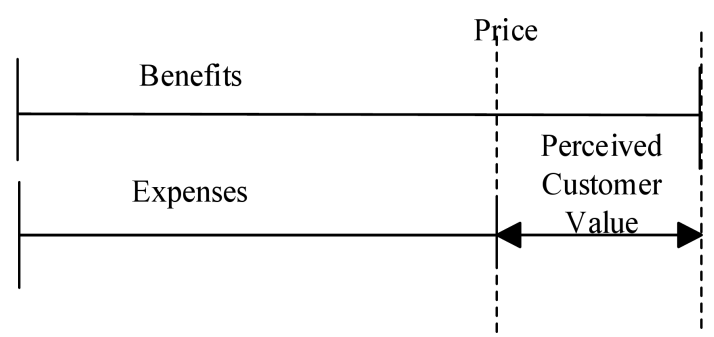

Fig. 1. Customer perceived value [45].

Customer perceived value is rooted in three key concepts, components of value, roles and perceptions and the importance of competition. The value offering can be constantly improved through feedback. There are challenges to value improvement as introduced by Miles (1961). First, time shortage is a challenge because in the cycle of a product, the quick pace gives little time for the customers' requirements to be known. Second, tests and measurements reveal performance and quality. However, measuring value is not as easy as performance measurement. Third, the human biases, misunderstandings and frictions inherent in human communication make value analysis more complicated. Fourth, the constant introduction of innovative products and processes makes value obsolete. In today's era of information technology however, this challenge can be overcome. By means of connectivity tools data acquisition is easier than ever [36].

\section{Customer value}

Customer perceived value is value of the market offering as seen by the customer. They tend to accept the one that they perceive offers the best value relative to the competitive offerings [45]. Value itself was studied according to literature in the past sec- tion. A variety of aspects have been studied when it comes to value literature.

The firm builds value elements around the core product in an attempt for greater returns. However, there might be a chance that by disregarding the customers' perspective the value added is not aligned with actual customer needs [46]. Hence it is crucial to assess value the way customers see it as well. The evaluation of quality takes place in the context of a comparison. The same can be said about value [23].

An offering is a bundle of benefits and costs. Benefits and costs are not all monetary and are not easily comparable at times [16]. To assess value, the benefits and costs must be clearly defined, either tangible or intangible, monetary or nonmonetary. They must also be translated into monetary terms as much as possible so as to be comparable. Anderson and Narus (1998) suggest making an inclusive list of all the value elements [48]. In this section an attempt has been made to gain an insight into what scholars propose as benefits and costs. It is important to keep in mind that here, just as mentioned before, the benefits and costs are as perceived by customer [18]. Table 2 summarizes the elements that constitute benefits and sacrifices from customers' perspective categorized as product, service and relationship benefits and sacrifices.

Wilson and Jantrania (1995) categorizes value elements into economic, strategic and behavioural elements in the business market context [51]. The purchase decision is made by an evaluation of the trade-off between costs and benefits [23]. Karimian Pour (2015) has disseminated value elements [53]. Figure 2 integrates the benefit and expense elements described above in the value framework.

In an empirical analysis of value, Ulaga and Chacour (2001) associate importance in form of a percent to each of the attributes that the offering is made of. The evaluation of benefits is done from two dimensions, the importance of the benefit and the performance of the firm in delivering them [48].

Table 2

Value elements.

\begin{tabular}{l|l|l|l}
\hline & Product & Service & Relationship \\
\hline Benefit & Alternative solutions [42] & Responsiveness [42, 48] & Image [42, 48] \\
& Product quality [42] & Trust and credibility \\
& Product customization [42] & Access [20] & Solidarity [46] \\
& & Reliability [42, 48] & Technical competence [49] \\
& & Service customization [42] & \\
\hline Expense & $\begin{array}{l}\text { Price [42] } \\
\text { Searching, order and acquisition cost [35] }\end{array}$ & $\begin{array}{l}\text { Installation cost [50] } \\
\text { Education cost [50] }\end{array}$ & \\
& Operation cost [35] & Maintenance and repair cost [50] & Conflict [42] \\
& Switching cost [35] & & \\
\hline
\end{tabular}


Management and Production Engineering Review



Fig. 2. Benefit and expense breakdown in value analysis [53].

For measurement the two dimensions are multiplied [1]. They are then compared to rivals alongside the costs. Value dimension assessment can be done through direct and indirect survey questions, conjoint analysis and focus groups and field tests, all of which give the company an insight into the customers' perception of functionality, performance and worth of the offering [48]. One of the purposes of marketing research is for determining customer value by discovering the different elements of benefits and sacrifices. Once the supporting data is gathered, the monetary value of each element is estimated [48].

The core and basic offering can be suggested as what Anderson and Narus (1998) call naked solutions. These offerings can then be complimented with features that provide value to each customer without costing both the company and the customer for value drains. Interestingly costs and benefits do not seem to carry the same weight for the customer. Cost reduction is valued more than benefit increase. For different customers, each element has a different significance as well because of their different needs, values, preferences and financial resources. In order to investigate customer value, the firm must start by viewing the customers' value chain to provide a performance enhancing link in the value chain [46].

As Anderson et al. (2006) point out, customer value is sometimes, through short-sighted view, considered beneficial only for advertising and promotion. However, this prevents the company from reaping the benefits that value can bring to superior business performance. Once the information needed is outlined, a subjective, theoretical approach is issued [13].

\section{Customer lifetime value}

While customer value is the value of the offering as perceived by the customer, customer lifetime value is the value of an individual customer to the organization. Hence, these views on value co-exist, with customer value at the core [39]. Customer lifetime value is one side of the coin. Value is a convincing guideline to support the decision to invest in serving a certain customer.
There is always a chance that customers do not find an in-depth relationship with the supplier very appealing. They might prefer having several suppliers for either variety or leverage. Some might find relationship management activities by the supplier company too much. Another concern might be about confidentiality issues [54]. These complications clarify the importance of the selection of high value customers. Customer's value to the firm has been studied in literature as customer lifetime value. Customer lifetime value, simply put, is the trade-off between the benefit that the customer has for the firm and the expenses it imposes.

The assessment of a customer's value starts with the economic value, is followed up by the strategic value and is concluded with a qualitative evaluation of the value of behavioral elements [46]. Customer lifetime value can be analyzed with criteria such as strategic importance, customer significance, loyalty coefficient and customer profitability [7].

The customer profitability is a good starting point for customer analysis, since it is a crucial element and relatively easy to determine. Reichheld (1994) suggests that the net present value of a customer can be calculated by knowing how long the customer will remain with the company, and estimating how much profit they bring and their net present value. There are four ways a long-term customer can provide value for the supplier, which must be considered when customer value is being contemplated [38] such as increased purchases, reduced operating costs, referrals and price premium.

The business customers grow and so does their purchase quantities. With a relationship view, the orders go to one single supplier. The profit can come because of the experience the customers acquire, so there is less resource demand on the supplier. Besides, the operations become more routine and as a result less mistakes will occur. The marketing costs go down by retaining the most profitable customers [55]. The long-term partners can act as a promotion agent by referring the company to the other actors [54]. Last, Doyle (2008) claims that the new 
customers are more price sensitive until the trust is established [7]. However, there is always the possibility that the partner customers would ask for privileges. The benefits and costs from the customer to the company are summarized in Table 3 .

These benefits and expenses are integrated into the value framework to demonstrate the analysis of customer lifetime value. This analysis is depicted in Fig. 3.

This analysis results in a more beneficial target market for the resources to be focused upon. Kim et al. (2006) have categorized the methods as using only life time value (LTV) Life time value (LTV) components or value and other information [56]. First, the customers are sorted based on their lifetime value. The list is divided by per-centiles. The second method considers the components used in LTV calculation, for instance current value, potential value and customer loyalty. These components are then used to segment the customers. The last method is introduced as the most meaningful method for segmentation. In this method LTV segmentation is paired with other information such as managerial information of socio-demographic information and transaction history.
The customer choice is the choice of not only the customer but also its surroundings, whether it is political, technological, competitive or social. Segment choice is as much about the customer as it is about the strategic group to compete against [57]. The macro environment effects the industry dynamics and customer behavior and goals. The political, economic, social, technological, environmental, and legal factors compose the macro environment. The ideal customer adds significant value to the offering whilst carrying minimum risk [1]. Successful partnerships between entities in the value chain happens based on eight principles: individual excellence, importance, interdependence, investment, information, integration, institutionalization and mutual trust (Kanter cited by Christopher et al. 2008).

The final decision to forsake a customer is reasons like incompatibility with core competence [58], lack of cost-effectiveness, market domination or monopoly $[59,60]$, incompatibility with past segments, segment size, growth and stability [61].

Eventually the analysis of customer's value for the firm clarifies which segment or even individual customer to target. These targets are the most potentially profitable target customers.

Table 3

Customers' benefit cost trade-off for the firm.

\begin{tabular}{l|l}
\hline \multicolumn{1}{c|}{ Benefits } & \multicolumn{1}{c}{ Expenses } \\
\hline Sales revenue & Cost of goods sold \\
Spare parts sales & Cost of spare \\
Data revenue & Installation \\
Analysis revenue & Customization \\
Consulting revenue & Infrastructure \\
Valuable data for 3rd party & Analysis and consulting \\
Referrals & Maintenance \\
Valuable feedback & Education \\
Network connections & Conflict \\
& Acquisition and retention \\
& Alternative customers \\
\hline
\end{tabular}

\section{Customers' benefit to firm



Fig. 3. A detailed analysis of value. 


\section{The innovation introduction}

The project was initiated as a research based industry project. There are three partner companies that had a significant role in the development of this project. Interestingly, they are from different industries, mining, sanitary porcelains, lime-stone based products. However, it is believed that they all work with ceramics and through the same processes.

The ceramic components are increasingly used in several applications due to resistance to their unique characteristics such as wear, high temperature and corrosive environment. In the manufacturing process for all three clients, ceramic particles need to be suspended in liquid. The properties of this suspension determines the properties of the final components. Particle control in suspensions is a crucial step in certain industrial processes. The homogeneity, or even dispersion of particles in the suspension, is essential [62]. Many industrial processes involving particleliquid mixtures are improperly monitored because they cannot be measured. There are very few devices that can be installed in the process to provide real time data on the mixtures, each with certain technical shortcomings. In the industries these days, the investigation of mixtures is done by taking samples from the process and running tests on them inside the laboratory.

This method has certain drawbacks. The most evident of which is the speed and convenience of the testing. The unfavorable results of the traditional measurement methods are the inefficient use of resources, low product quality, testing complications and instability of the process. By the time a sample is taken from the process and tested in the laboratory, the process has gone on for some time. The tests might demonstrate unfavorable characteristics in the mixture, but the process has been going on, consuming raw material and energy. These push the production away from lean production. The company incurs extra cost and produces waste, or substandard quality. Getting samples from large vessels, transportation to laboratories for testing is a challenge all by itself [62]. Laboratories also require resources to be built and maintained. Besides, the laboratory staff need a certain skill set. What is more, the result of the testing cannot provide real time feedback for the process to help make it more efficient.

The laboratory analysis of slurries that flow through the process, is a weak link in production process. Laboratory testing takes time and resources, and is still not efficient. This process need is an opportunity for innovative thinking. The need for a non-invasive, inexpensive, fast in situ measurement has always existed [62].

The passive resonance sensor can monitor particle suspensions. This method does not require a very complex test setting. The ease of installation and maintenance make it a perfect choice for industrial purposes. An electrical analyzer was developed that measured homogeneity, particle size and changes and electrical state of particles online. The data is then saved and aggregated and sent to clouds. The aim is to analyze the data in the firm itself. Based on the analysis then feedback, solution and consulting is offered to the client company.

Smart connected products are composed of three elements: physical components, smart components and connectivity components. Physical components are the mechanical and electrical parts. Smart components are the sensors, microprocessors, data storage, controls, software, operating system and user interface. These components amplify the physical components. Connectivity components are the protocols that enable connection with the product and amplify the performance of the smart components. Connectivity allows information to be exchanged and also enables some functions to exist outside. Connectivity can be to one or many other products or even between numerous products in a network for data transmission [63]. In this innovation's case there are also three elements the electrode, the signal generator and the raw data collector.

In order to make the device cheaper, the team is trying to eliminate all the unnecessary features and make a small efficient low cost device for this purpose. All that is expected from the raw data collector is to minimize the data a bit. However, the industrial computers with their graphic interface are too complicated and too expensive for such simple matter. Figure 4 depicts the final vision of the team for the offering.



Fig. 4. The process aimed for.

In this offering, the sensor and the signal generator are inside the company. The data is then sent to the cloud and the analysis is done by the firm. The development of smart and connected devices has inspired this marketing mix. This new paradigm is quickly making its way to every industry. 


\section{Value analysis}

\section{The offering}

The product is a smart and connected device. It can be considered on three different levels, the measurement device, the data collector and the cloud system.

In order to design the product, the other methods of measurement were studied. The technology is very interesting compared to the other measurement methods. There are three measurements that are essential for suspension control. The passive resonance technology, contrary to the other methods, measures all three. Table 4, positions the methods based on what attributes they measure.

Table 4

The positioning of methods.

\begin{tabular}{l|c|c|c}
\hline \multicolumn{1}{c|}{ Method } & Homogeneity & $\begin{array}{c}\text { Particle } \\
\text { size and } \\
\text { changes }\end{array}$ & $\begin{array}{c}\text { Electrical } \\
\text { state of } \\
\text { particles }\end{array}$ \\
\hline $\begin{array}{l}\text { Atomic Force } \\
\text { Microscopy }\end{array}$ & $\times$ & $\times$ & \\
\hline $\begin{array}{l}\text { Digital video } \\
\text { Microscopy } \\
\text { Particle } \\
\text { tracking analysis }\end{array}$ & & & \\
\hline $\begin{array}{l}\text { Dynamic light } \\
\text { scattering }\end{array}$ & & $\times$ & \\
\hline $\begin{array}{l}\text { Electrophoretic } \\
\text { light scattering }\end{array}$ & & & \\
\hline $\begin{array}{l}\text { Electroacoustic } \\
\text { analysis }\end{array}$ & & $\times$ & $\times$ \\
\hline $\begin{array}{l}\text { Electrical resis- } \\
\text { tance topography }\end{array}$ & $\times$ & & \\
\hline $\begin{array}{l}\text { Ultrasound } \\
\text { Spectroscopy }\end{array}$ & & & \\
\hline
\end{tabular}

The other part of the product, is the data collector part of the device. The challenge at this point is to omit the extra features to make the device cheaper, more compact and user friendly. Once this challenge is overcome, the cloud part can be planned. The cloud system is the most expensive investment as admitted by the project manager. It is crucial for the cloud system to be confidential and reliable.

The data collection is not the biggest challenge though. The problem is not knowing what kind of analytics must be run on the data and how they must be used. The analytics must lead to valuable information that increases efficiency. It must also add value to the customer's process and product. The data becomes of value once it has implications for the business process. Analysis of trends, forecasting and standardized reporting are crucial in the big data analysis service offering. Cases, analytics, solutions, optimization, work flow and simulations communi- cate the value to the customers. Data visualization, possible scenarios and statistical analysis can have significant impact on the value added for business processes [64].

This innovative solution is the mix of a measurement device for ceramics industrial processes and the service offering based on data analytics.

\section{The service}

The service offering requires a certain infrastructure at the company's future organization. Software and hardware for storing and analysis in addition to the cloud are needed. This technology requires huge initial investment and a set of skills to build, use and maintain. The human resources are to be skilled in data analysis and data based consulting.

The low price of the measurement device requires the value capture to happen through customizable service offering. Hence it is really important to plan the value capture and appropriation model. In service based on smart and connected devices, there are several ways to use and monetize the data generated. In this business model it is crucial to answer the following questions: Where is the data generated? What kind of implication does the data have for different network constituents? Which network constituent would deem the data valuable?

The advent of the cloud concept is leading to fundamental changes in the way value is created and captured. There are new opportunities for all the industries that are otherwise established. The emergence of sensors and the generation of big data combined with the possibilities offered by cloud is what motivated the project team in the first place. The project team's initial analysis was that a mix of the following elements would be a lucrative and differentiated offering: an easy to use yet robust measurement device and data-based analysis, control and feedback for increased efficiency.

The demo companies are interested in devising a delivery chain. Partner company number one manufactures mining devices. The idea is to install the measurement device and sell them alongside their own product. This has a bright horizon of hundreds of devices per year. Partner company number two is planning to use this system for their very innovative and clearly confidential project. Once successful, they are planning to sell the device to other similar companies who can put it to use. The third partner company is a daughter company to a more global and significant company. They have also suggested that the offering will be marketed to the sister companies. The case company network is demonstrated in Fig. 5. 


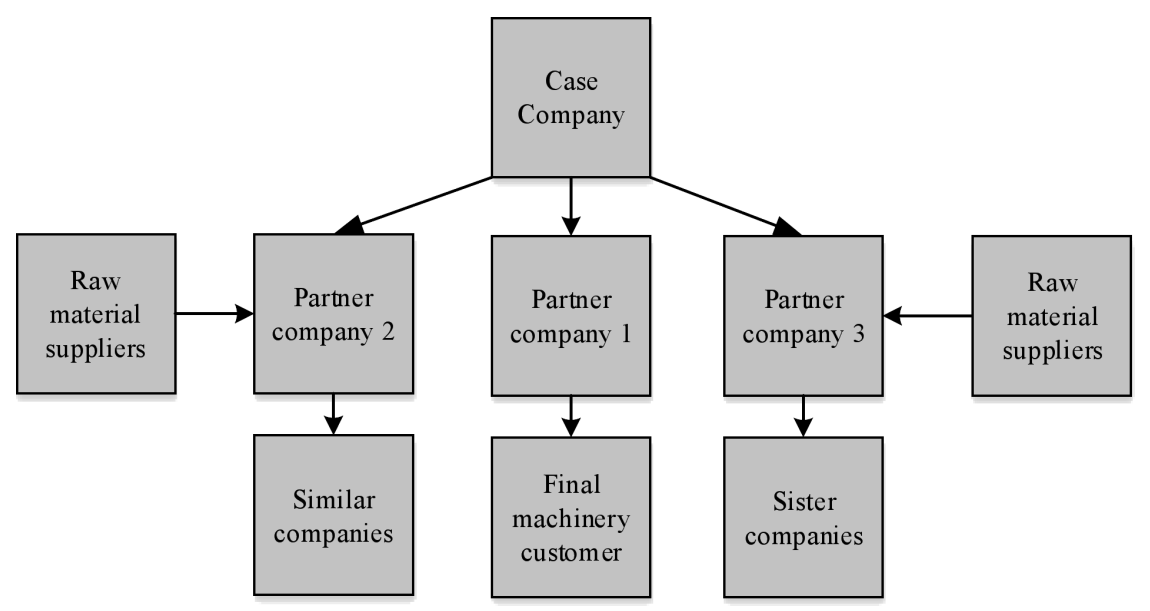

Fig. 5. The case company network.

The service can be offered to the company, the end customer or the material supplier. The case company can monetize their service offering by offering monitoring, optimization, control and autonomy to each of these three constituents. The following analysis discusses how these functions can generate value for each entity, while considering how the project team can appropriate value. In order to analyze value from different perspectives the different entities involved in the project are depicted in Fig. 5.

The data and its analysis can be the basis for a different value proposition to each entity. Since all the partner companies are multinational ones with production all around the globe, the data collection from the different sites can assure consistency. In multinational companies the raw material suppliers might not be similar, which might change the consistency of the quality of the final product. Besides, the measurement device can be installed at different points in the process to pinpoint the origin of the problem in the process.

The first partner company manufactures mining machinery and is planning to install the measurement device on the machinery. This could offer the case company two areas for service. On one hand, based on the data generated, it can monitor the mining machine's performance and give feedback to the partner company for improved after sales service. On the other hand, it can partner with the raw material suppliers of the end users of the mining machinery.

In addition, they can become partners with the end users themselves. Getting data from such numerous end customers helps the case company benchmark different users against each other. By means of partnership the case company can detect the best practices, which can give them a leverage for consulting the whole customer base for enhanced perfor- mance. What is more, the mining machinery might require remote control due to the lack of safety in their environment. This might be feasible through integration of certain features in the measurement device.

As far as the second customer company is concerned, the measurement device assists with the efficiency of the process. In this application, the measurement device tracks the process until it reaches the desired state. The time required for this state to be reached is different. The measurement device ensures that as soon as this state is reached, the process stops to ensure efficiency. The data collected from the process, the suspension and the environment can give the company insights into how the process can be developed. The different trends and process data collected at the case company's site can give them a rich background for analysis and process benchmarking.

If the case company wishes to monetize the service by offering data based services to different entities, there are certain considerations. First, the data access must be fully discussed. The consent of different entities for data use and sharing must be obtained. Confidentiality issues must be resolved before they lead to complexities in the relationship with partners. In order for the data based service to be the point of differentiation in this case, two sides of it must be taken into account: data presentation and visualization and consulting for improvement.

The company must decide, perhaps even together with the client, what data is shared. Since the case company has decided that the data analysis is done in their headquarters, the raw data is not presented to the client except for special cases, in which it must be discussed. The visualization of the analysis then must be clear and useful for different members of the 
purchase team. It must be helpful for the users of the machines to be able to discuss improvement points with the top managers.

The consulting service based on the data, is a lucrative business for the case company. The company can then gather different data, from different clients. The learning from each client, can be utilized indirectly for improvement of the others. The efficiency of the processes, the raw material and the environment on one client site can inspire the team to provide some insights that would enhance the other client's processes.

\section{Smart and connected value analysis}

The double-sided view on value is a well-rounded analysis at this point in the project. The company is in the commercialization stage, which means their means are limited and taking the right approach can make a huge difference. This offering can improve the client processes immensely. The benefits of this offering once put to use in the client process results in improvements as illustrated in Fig. 6.

The easy to use and maintain measurement device does the job done previously by laboratory employees through time, this removes the need for laboratory procedures and work force. As a result of real time monitoring, any fault in the process is known. The process is halted just in time, which leads to less waste of time and material. Since the data saving and analysis components of the system is located in the company and the client only owns the simple measurement device, it is a cheaper investment to begin with.

Given that the experts in the company analyze the date, they have a broader view on the matter. They analyze data from different clients and can provide better insights compared to an in house analyst. The analysis can help the client choose better raw material for their processes and all in all results in better final product quality. The perks of this offering are known.
The expenses imposed on the client are a result of the value appropriation model crafted by the company. The device is practically free due to its low development cost. Besides, crossing out the data storage and analysis components results in a cheaper measurement device in general. The client is then charged for data storage on the cloud base owned by the company. They are then offered consulting to the extent that they find helpful and are charged accordingly.

The customer on the other hand must also be valuable over its lifetime for the company to pursue. The sales make up a small part of the benefit the customer offers since the measurement device is not priced so highly. What matters most is how valuable the data analysis and consulting that the company offers to the client based on the measured data is and how much they are willing to pay for them. This is the service fee that the company later charges the client over the lifetime of their cooperation.

There are certain indirect benefits that the client company has. First, the data from the client company can be put to use for consulting offered to a third party, for instance the raw material suppliers. This is of course with regard to the terms of agreement about the data confidentiality. In order for the company to exploit the data they have fully by offering service to other entities, the data does not have to be shared even. They can offer consulting without disclosing the data generated from the processes. If a client's data creates opportunities for the company to offer service to other entities, the client is more valuable to pursue for the firm.

Another indirect benefit that having a strong player as a client has is the references and access to new clients or delivery chain that it offers to the company. The partner clients chosen so far have created a delivery method for the company's products by featuring them on their machines and referring to their sister companies.



Fig. 6. The impact of the offering on the process. 
The expenses that are inherent in the business for the company are to be considered as well. The firm needs a significant initial investment for the cloud platform and the storage and analysis computers. The development of the measurement device is also an expense in the initial phase. Once the measurement device starts running there is need for people who do the analysis and consulting and hence impose a service cost on the company. There is also an indirect cost, which is the sales and prospects that the company loses by choosing one client. The client rivals might choose not to partner with the company anymore, in which case the client company's lifetime value must compensate for it.

\section{Discussion}

Success in markets is oriented around value [5-7]. A firm must find a unique way to create value and capture it in return. Value is the difference between the benefits sought and the expenses imposed [7, 29].

Services are the new value adding elements in the modern marketing paradigm [61]. Value proposition must be compelling enough for the prospective customers to agree to cooperate with the firm in a relationship-based co-creative attempt.

The partners for the service must be chosen considering the costs and benefits they have for the firm [38]. If the service concept is to be developed for each partner customer, it is crucial that they have a lucrative lifetime value. For newly founded businesses this is even more important. They have limited means and the choice of partner can enhance their business both in the present and in the future.

The partner's means must create favorable financial returns for company. The relationship must also create value for the firm. During the crafting of the offering, the client insights can have major effects on the success of the final offer. For market development of the product and services, the client network can be a great asset for the company. This is where the customer lifetime value and the value offered to the customer are intertwined. This study developed a framework that brings the two analyses together. This thorough analysis is illustrated in Fig. 7.

The value framework must give an understanding of the following questions: Which customers have high lifetime value as partners? What are the value elements for the prospective partners? How to create superior value through a product- service concept?

The case company aimed to offer a measurement device paired with analysis of the data stored in cloud. In other words, a product-service mix. This product-service mix is then analyzed from the value point of view according to the thorough value framework introduced in this thesis. This analysis is presented in Fig. 8.

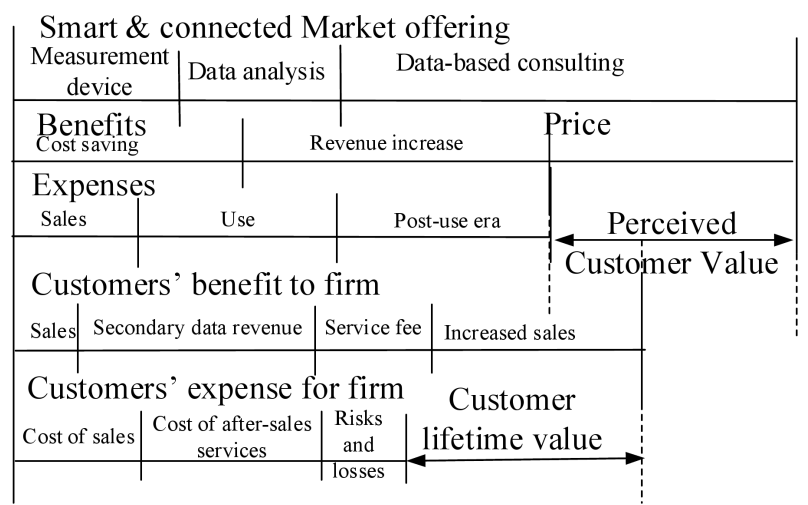

Fig. 7. A dual perspective analysis of value.



Fig. 8. The dual value analysis of the project. 
The case project of this thesis proved the importance of value analysis in the development stage of a service and product solution for the cost-reduction and efficiency increase of an industrial process. The value analysis demonstrated how perceived customer value and customer lifetime value are closely interrelated. The analysis of this relationship can help the decisions about partner and future clients and offering mix.

First, the clients who believe in the technology are chosen as partner clients. What is more, their company must allow information to flow freely in the process of the development. It is preferred also that they are strong players in the market so that later their reputation and network can be used for the development of the offering. The company could also consider how the partner client's data could be used as a basis for service offering to the other members of their network. Their rivalry with other players in the industry must not pose as a threat to the company's future growth. Their processes must be suitable for the generic design of the measurement device to be developed so that it can be utilized in different industries.

Second, the value analysis can form a background for future client selection. Considering how the company has limited means it is important to target clients with the most lifetime value. The value analysis puts forth a method for comparing clients on a general scale in order to prioritize them.

Last, the value analysis can guide the design of the offering. The clients who have the most customer lifetime value are the ones who dictate the product design. Their insights and processes must be taken into account throughout the design. Besides, their needs and preferences are to be taken into account in the service offering paired with the product.

The idea of value the company wanted to offer went through changes during this phase. In the very beginning the focus was on the measurement device to generate some revenue. As the studies went on and the value of service became clear, the revenue source also became the service part of the offering, because it was the differentiation factor.

The reviews of similar rival products and their evolution from laboratory testing devices to full solutions, brought to light the benefits sought for. Through the study of smart and connected products and characteristics exclusive to them, their potential for creating different revenue sources was discovered. The idea of having multiple revenue sources from the same data set was presented to the project team.

In spite of the impact of this study on the direction of the project there were certain limitations.
During the running time of this thesis, there were still some improvements being carried out on the measurement device and technology. This did not allow for the framework developed to be put in practice fully. It was merely a tool for idea generation. Perhaps, in practice, value elements change.

Besides, the competitor analysis and working with the partner client companies were being done by two different members of the team. Although through meetings and discussions, the observations were shared, there was a certain barrier between the practice and the theory. As a result this framework might be too preliminary and simplified compared to a real life situation.

\section{Conclusions}

\section{Managerial implications}

A carefully devised business model and value appropriation plan results in a better value for the company itself as well. With the advent of revolutionary technologies such as the cloud systems, the value appropriation and delivery is going through changes as well. In the past value used to be created by one entity and delivered to the client. Nowadays, value is being created cooperatively by the two entities. This emphasized the need for a thorough view on the value of this cooperation for both.

The objective of this study was to attain a dual perspective of value. In order to attain this goal customer value and customer lifetime value are studied and put together in one single but complete framework. To manage to introduce the concept a theoretical literature review was carried out for the development of a framework. Then the framework was applied to a real life project for the value analysis of an innovative product-service mix in its commercialization stage. This product-service bundle is of smart and connected nature.

What makes this framework interesting is that it was developed for an offering with the different elements of product, service and relationship. Being all inclusive it brings to light all the benefits and expenses of the offering that might otherwise be overlooked. In the specific case it is applied to service made possible by the cloud technology which is even more useful in the present era. The specific service capabilities of the cloud systems are analyzed through benefits and expenses lists. The value appropriation and capture model and how it changes for cloud based services were also discussed. How the data gathered from one entity can be a great resource for the firm to generate separate income. 


\section{Future research}

However, this framework has been developed in one specific case in one industry. The framework is simplified to the benefit and expense elements that are exclusive to this specific case. For different cases there might be more elements that can be exploited as benefits or must be focused on for reduction as expenses. The framework can then be generalized further. A general frame work applicable for any product-service mix can be beneficial to the analysis of value in modern marketing processes.

The project is supported by OTKA (K 115542).

\section{References}

[1] Kothandaraman P., Wilson D.T., The future of competition: value-creating networks, Industrial Marketing Management, 30, 379-389, 2011.

[2] Chesbrough H., Rosenbloom R.S., The role of the business model in capturing value from innovation: evidence from Xerox corporation's technology spinoff companies, Industrial and Corporate Change, 11, 3, 529-555, 2002 .

[3] Drucker P.F, Innovation and Entrepreneurship, Butterworth Heinemann, 2007.

[4] Jain D., Singh S.S., Customer lifetime value research in marketing: a review and future directions, Journal of Interactive Marketing, 16, 2, 34-45, 2002.

[5] Slywotzky A.J., Value migration: how to think several steps ahead of the competition, Harward Business School Press, 1996.

[6] Woodruff R.B., Customer value: The next source for competitive advantage, Journal of the Academy of Marketing Science, 25, 2, 139-153, 1997.

[7] Doyle P., Value-based marketing: marketing strategies for corporate growth and shareholder value, $\mathrm{Wi}$ ley, 2008

[8] Cannon H.M., Morgan F.W., A strategic pricing framework, Journal of Services Marketing, 4, 2, 19 $30,1990$.

[9] Ingenbleek P., Frambach R.T., Verhallen T.M.M., The role of value informed pricing in market oriented product innovation management, Journal of Product Innovation Management, 27, 7, 1032-1046, 2010.

[10] Slater S.F., Developing a customer value-based theory of the firm, Journal of the Academy of Marketing Science, 25, 2, 162-167, 1997.

[11] Ulaga W., Eggert A., Value-based differentiation in business relationships: gaining and sustaining key supplier status, Journal of Marketing, 70, 1, 119136,2006 .

[12] Woodruff R., Customer value: the next source of competitive advantage, Journal of the Academy of Marketing Science, 25, 2, 139-153, 1997.

[13] Anderson J.C., Narus J.A., van Rossum W., Customer value propositions in business markets, Harvard Business Review, 84, 3, 90-99, 2006.

[14] Keränen J., Jalkala A., Three strategies for customer value assessment in business markets, Management Decision, 52, 1, 79-100, 2014.

[15] Piercy N.F., Morgan N.A., Strategic and operational market segmentation: a managerial analysis, Journal of Strategic Marketing, 1, 123-140, 1993.

[16] Anderson J.C., Wynstra F., Purchasing highervalue, higher-price offerings in business markets, Journal of Business-to-Business Marketing, 17, 1, 29-61, 2003.

[17] Jaworski B.J., Kohli A.K., Market orientation: antecedents and consequences, Journal of Marketing, $57,3,53-70,1993$.

[18] Day E., The role of value in consumer satisfaction, Journal of Consumer Satisfaction, Dissatisfaction and Complaining Behavior, 15, 22-32, 2002.

[19] Holbrook M.B., Customer value and auto ethnography: subjective personal introspection and the meanings of a photograph collection, Journal of Business Research, 58, 1, 45-61, 2005.

[20] Parasuraman A., Reflections on gaining competitive advantage through customer value, Journal of the Academy of Marketing Science, 25, 2, 154-61, 1997.

[21] Smith J.B., Colgate M., Customer value creation: a practical framework, Journal of Marketing Theory and Practice, 15, 1, 7-23, 2007.

[22] Palmer R.A., Millier P., Segmentation: identification, intuition and implementation, Industrial Marketing Management, 33, 779-785, 2004.

[23] Zeithaml V.A., Consumer perceptions of price, quality, and value: a means-end model and synthesis of evidence, Journal of Marketing, 52, 3, 2-22, 1988.

[24] Sheth J.N., Newman B.I., Gross B.L., Why we buy what we buy: a theory of consumption values, Journal of Business Research, 22, 2, 159-170, 1991.

[25] Anderson J.C., Jain D., Chintagunta P., Customer value assessment in business markets: a state of practice study, Journal of Business-to-Business Marketing, 1, 1, 3-29, 1993.

[26] Butz Jr. H.E., Goodstein L.D., Measuring customer value: gaining the strategic advantage, Organizational Dynamics, 24, 3, 63-77, 1997. 
[27] Grönroos C., From marketing mix to relationship marketing, Management Decision, 32, 2, 4-20, 1994.

[28] Gassenheimer J.B., Huston F.S., Davis J.S., The role of economic value, social value, and perceptions of fairness in interorganizational retention decisions, Journal of the Academy of Marketing Science, 26, 4, 322-337, 1998.

[29] Kotler P., A generic concept of marketing, The Journal of Marketing, 36, 2, 46-54, 1972.

[30] Eggert A., Wolfgang U., Customer perceived value: a substitute for satisfaction in business markets? Journal of Business \& Industrial Marketing, 17, 2/3, 107-118, 2002.

[31] Woodall T., Conceptualising 'value for the customer': an attributional, structural and dispositional analysis, Academy of Marketing Science Review, 12, $1-42,2003$

[32] Liu A.H., Customer value and switching costs in business services: developing exit barriers through strategic value management, Journal of Business \& Industrial Marketing, 21, 1, 30-37, 2006.

[33] Han S.L., Sung H.S., Industrial brand value and relationship performance in business markets - a general structural equation model, Industrial Marketing Management, 37, 7, 807-818, 2008.

[34] Blocker C.P., Modeling customer value perceptions in cross-cultural business markets, Journal of Business Research, 64, 5, 533-540, 2011.

[35] Khalifa A.S., Customer value: a review of recent literature and an integrative configuration, Management Decision, 42, 5, 645-666, 2004.

[36] Miles L.D., Techniques of value analysis and engineering, New York McGraw-Hill Book Company, 1961.

[37] Pynnönen M., Ritala P., Hallikas J., The new meaning of customer value: a systemic perspective, Journal of Business Strategy, 32, 1, 51-57, 2011.

[38] Day G., Fahey L., Valuing market strategies, Journal of Marketing, 52, 3, 45-57, 1988.

[39] Reichheld F.F., Loyalty and the renaissance of marketing, Marketing Management, 2, 4, 10-21, 1994.

[40] Treacy M., Wiersema F., The disciplines of market leaders, reading, MA: Addison-Wesley, 224, 1994.

[41] Monroe K.B., Price: making profitable decisions, New York: McGraw- Hill, 1990.

[42] Chen Z., Dubinsky A.J., A conceptual model of perceived customer value in E-Commerce: a preliminary investigation, Psychology \& Marketing, 20, 4, 323-347, 2003.
[43] Lappierre J., Customer-perceived value in industrial contexts, Journal of Business and Industrial Marketing, 15, 2/3, 122-140, 2000.

[44] Huber F., Herrmann A., Morgan R.E., Gaining competitive advantage through customer value oriented management, Journal of Consumer Marketing, 18, 1, 41-53, 2001.

[45] Lyly-yrjänäinen J., Velasquez S., Suomala P., Uusitalo O., Introduction to industrial management, Tampere University of Technology, Department of Industrial Management, 2010.

[46] Lindgreen A., Hingley M.K., Grant D.B., Morgan R.E., Value in business and industrial marketing: Past, present, and future, Industrial Marketing Management, 41, 1, 207-214, 2012.

[47] Ravald A., Grönroos C., The value concept and relationship marketing, European Journal of Marketing, 30, 2, 19-30, 1996.

[48] Anderson J.C., Narus J.A., Narayandas D., Business market management, Pearson, Prentice Hall, 2009.

[49] Ulaga W., Chacour S., Measuring customer perceived value in business markets - a prerequisite for marketing strategy and implementation, Industrial Marketing Management, 30, 6, 525-540, 2001.

[50] Parasuraman A., Zeithaml V.A., Berry L.L., A conceptual model of service quality and implications for future research, Journal of Marketing, 49, 41-50, 1985.

[51] Ulaga W., Capturing value creation in business relationships: a customer perspective, Industrial Marketing Management, 32, 8, 677-693, 2003.

[52] Wilson D.T., Jantrania S., Understanding the value of a relationship, Asia-Australia marketing journal, 2, 1, 55-66, 1995.

[53] Karimian Pour N., Fully functional mock-ups in constructing value propositions, Tampere University of Technology Thesis, Faculty of Business and Built Environment, 2015.

[54] Lovelock C.H., Wright L., Principles of service marketing and management, Prentice Hall, 1999.

[55] Gummesson E., Return on relationships (ROR): the value of relationship marketing and CRM in business-to-business contexts, Journal of Business \& Industrial Marketing, 19, 2, 136-148, 2004.

[56] Kim S.Y., Jung T.S., Suh E.H., Hwang H.S., Customer segmentation and strategy development based on customer lifetime value: a case study, Expert Systems with Applications, 31, 101-107, 2006. 
[57] Doyle P., Saunders J., Market segmentation and positioning in specialized industrial markets, Journal of Marketing, 49, 24-32, 1985.

[58] Frank R.E., Massy W.F., Wind Y., Market segmentation, Englewood Cliffs, N.J.: Prentice-Hall, 1972.

[59] Anderson E.W., Firm, industry and national indices of customer satisfaction. Implications for services, Advances in Services Marketing and Management 2, 87-108, 1993.

[60] Mohr J., Sengupta S., Slater S., Marketing of high technology products and innovations, 2nd ed., Pearson, Prentice Hall, 2005.

[61] Viardot E., Successful marketing strategy for hightech firms, 3rd ed., Artech House Technology Management Library, 2004.
[62] Salpavaara T., Järveläinen M., Seppälä S., YliHallila T., Verho J., Vilkko M., Lekkala J., Levänen E., Passive resonance sensor based method for monitoring particle suspensions, Sensors and Actuators B: Chemical, 219, 324-330, 2015.

[63] Porter M.E., Heppelmann J.E., How smart, connected products are transforming competition, Harvard Business Review, November, 2014.

[64] Lavalle S., Lesse E., Shockley R., Hopkins M.S., Kruschwitz N., Big data, analytics and the paths from insight to value, MIT Sloan Management Review, http://sloanreview.mit.edu/article/big-dataanalytics-and-the-path-from-insights-to-value/, 2010 . 